\title{
LETTERS
}

\section{Reducing food insecurity and improving health with a basic income guarantee}

I read with interest Dr. Trevor Hancock's article, "Reducing the cost of inequality," in which he argued that poverty in Canada is now so expensive we cannot afford it. ${ }^{1}$ Public health teaches us that tackling poor health outcomes ascribed to poverty particularly those faced by Indigenous people - necessitates acting on upstream causes of inequality. As Dr. Hancock notes, public health is naturally eyeing innovative policies like the guaranteed income (or basic income guarantee) to improve health and offset the exorbitant costs of poverty.

As a negative income tax, a basic income guarantee works like this: if your income is below a specified threshold, you are topped up by a "no strings attached" government cash transfer. The poorest Canadians get the maximum transfer and the richest get nothing. No one falls below an after-tax minimum income.

One way a basic income guarantee may improve health outcomes is by reducing food insecurity, which is defined as inadequate or inconsistent access to nutritious food owing to financial barriers. ${ }^{2}$ Canada's northern and Indigenous communities are especially prone to food insecurity. Almost $26 \%$ of off-reserve Indigenous households are food insecure compared with $12 \%$ of all households in Canada. ${ }^{2}$ In Nunavut, where nearly $47 \%$ of the population is food insecure, groceries often cost two to three times more than the national average. ${ }^{3}$

Poor access to nutritious food negatively affects physical, mental and psychosocial health. Food insecurity is tied to higher rates of depression, asthma and heart disease. ${ }^{4}$ It makes managing chronic diseases like diabetes harder. ${ }^{4}$ Because fixed expenses are generally covered before budgeting for food, many Canadians living in remote communities buy cheaper, less nutritious food when money is tight.

Canada needs studies to assess the pros and cons of basic income programs, and to determine optimal designs in the Canadian context. For instance, transfers could be indexed to the higher cost of living in Canada's north. Alongside existing food subsidy programs like Nutrition North Canada, a basic income guarantee could empower impoverished populations by giving them the autonomy to better meet the needs of their families on their own terms. It would be expensive, with estimates ranging in the tens of billions of dollars, but it would accrue savings by replacing existing social assistance programs. ${ }^{5}$

At present, the province of Ontario is running a three-year pilot project in
Hamilton, Brantford, Brant County, Thunder Bay and Lindsay. ${ }^{6}$ Perhaps emerging evidence will show that a basic income guarantee can indeed reduce the cost of inequality by giving Canadians living in poverty more access to the nutritious food they need to lead healthy, fulfilling lives.

\section{Max A. Deschner BA MD}

Resident physician, Department of Medicine, Western University, London, Ont.

Cite as: CMAJ 2018 July 3;190:E804. doi: 10.1503/cmaj.69280

\section{References}

1. Hancock T. Reducing the cost of inequality. CMAJ 2018;190:E92.

2. Tarasuk V, Mitchell A, Dachner N. Household food insecurity in Canada, 2014. Toronto: Research to identify policy options to reduce food insecurity (PROOF); 2016. Available: http://proof.utoronto. ca/food-insecurity/ (accessed 2018 Feb. 22).

3. 2014 Nunavut food price survey: comparison chart. Montréal: Food Secure Canada; 2017. Available: https://foodsecurecanada.org/resources-news/ resources-research/2014-nunavut-food-price-survey -comparison-chart (accessed 2018 Feb. 22).

4. Vozoris NT, Tarasuk VS. Household food insufficiency is associated with poorer health. J Nutr 2003;133:120-6.

5. Martin D. Better now: six big ideas to improve health care for all Canadians. Toronto: Allen Lane; 2017.

6. Ontario Basic Income Pilot. Toronto: Government of Ontario; 2018. Available: www.ontario. ca/page/ontario-basic-income-pilot (accessed 2018 Feb. 22)

Competing interests: None declared. 